\title{
A shabti-box of Djehutyhotep (Turin Cat. 2443)
}

\author{
Paolo Marini
}

This paper focuses on an interesting and never before studied shabti-box (Cat. 2443) currently kept at the Museo Egizio, Turin. By consulting archival documents, the author has ascertained that the container comes from the collection sold by Bernardino Drovetti to King Carlo Felice in 1824. The box is inscribed for the $i m y-r 3$ pr and sšm(w)-ḥb $n$ Jmn Djehutyhotep. It has a $p r-n w$-chapel shape and is decorated with some very common funerary scenes. Its unusual combination of iconography from the Ramesside period and morphological characteristics from the Eighteenth Dynasty makes it a unicum, eluding habitual typological classifications. However, stylistic analysis and comparisons with other shabti-boxes indicate that the owner must have flourished during the reign of Ramesses II.

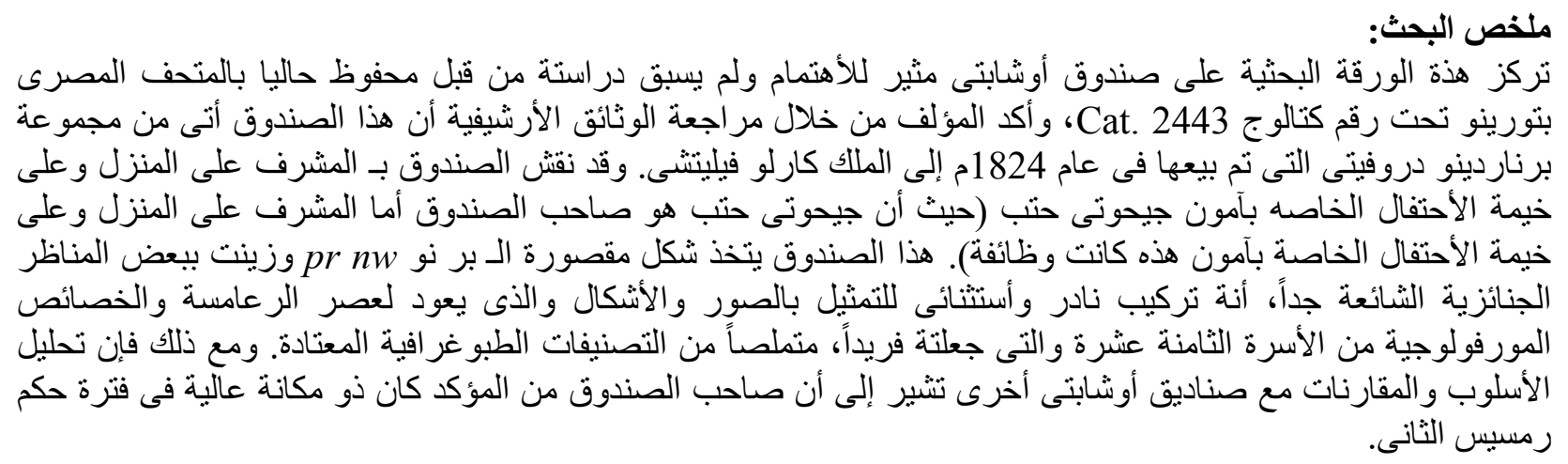

The collection of the Museo Egizio in Turin includes a shabti-box inscribed for an official named Djehutyhotep, listed as no. 2443 in the catalogue Regio Museo di Torino. Antichità egizie. ${ }^{1}$ In the collection there are presently 46 shabti-containers (Table 1: 22 wooden boxes, 3 pottery boxes and 21 shabti-jars). Most of them belong to the collection sold by the Consul General of France, Bernardino Drovetti, to King Carlo Felice of Savoy in $1823 .{ }^{2}$ This collection is the result of many years of activity by the Consul, beginning in 1806 with purchases on the Egyptian antiquarian market and followed by the gradual addition of antiquities from archeological excavations. ${ }^{3}$ Therefore it is often impossible to determine from which site the pieces originate. Shabti-box Turin Cat. 2443 is no exception to this rule. Furthermore, its typological classification and the identity of its owner are problematic, and this severely affects the possibility of exact dating. ${ }^{4}$
One of the oldest documents referring to Drovetti's objects is a list sent by Carlo Vidua to Count Prospero Balbo during the negotiations for the purchase of the collection. ${ }^{5}$ The document consists of a catalogue divided into nine categories: within each category, each entry describes only features that were of interest to antiquarians. ${ }^{6}$ Of course, shabti-boxes and shabtis were not recognized as such at the time and are accordingly not distinguishable in Vidua's list. Most probably, all shabti-boxes arrived as part of the Drovetti collection are included, along with other boxes with different functions, in the category "objets en bois". However, it is often impossible to identify them. Descriptions * 310 , *311 and *312 are an exception, as they correspond to some $p r-n w$ chapel-shaped shabti-boxes. ${ }^{8}$

The three entries are described as follows:

*310 Une caissette à trois divisions, avec figures et 
hiéroglyphes ; les couleurs sont de la plus parfaite conservation et fraicheur; 30 c. sur 15.

*311 Une idem à deux divisions; 22 c. sur 15.

*312 Une idem à une seule division; 32 c. sur 10.

The specific mention of the tripartite subdivision, the excellent preservation and the fraicheur of box *310 speak strongly for an identification with the shabti-box of Nefermesi (Turin Cat. 2445; Fig. 1), ${ }^{9}$ as does the fact that the latter's height and width 30 and $17 \mathrm{~cm}$, respectively - are very close to those given for this item in the list. This is a wooden shabti-box, (Type Marini IIIa - Type IV Aston), ${ }^{10}$ plastered and painted. It has a bottom with protruding edges and with four jambs, with a vaulted lid between each pair. The long sides are decorated with a scene showing the deceased offering to the gods: Osiris and Isis on the front, and Horus and Nephthys on the back. The short sides portray the four sons of Horus. ${ }^{11}$

The description of box *311 in Vidua's list suggests that it should be similar to the previous one, but bipartite. The only box in the Museo Egizio of Turin corresponding to this description is the shabti-box of Nia (Cat. 2444). ${ }^{12}$ Like the box of Nefermesi, it carries scenes of the deceased worshiping gods and the four sons of Horus (Fig. 2). The only obstacle against this identification are its - h. $30,5 \mathrm{~cm}$, base $25 \times 22$

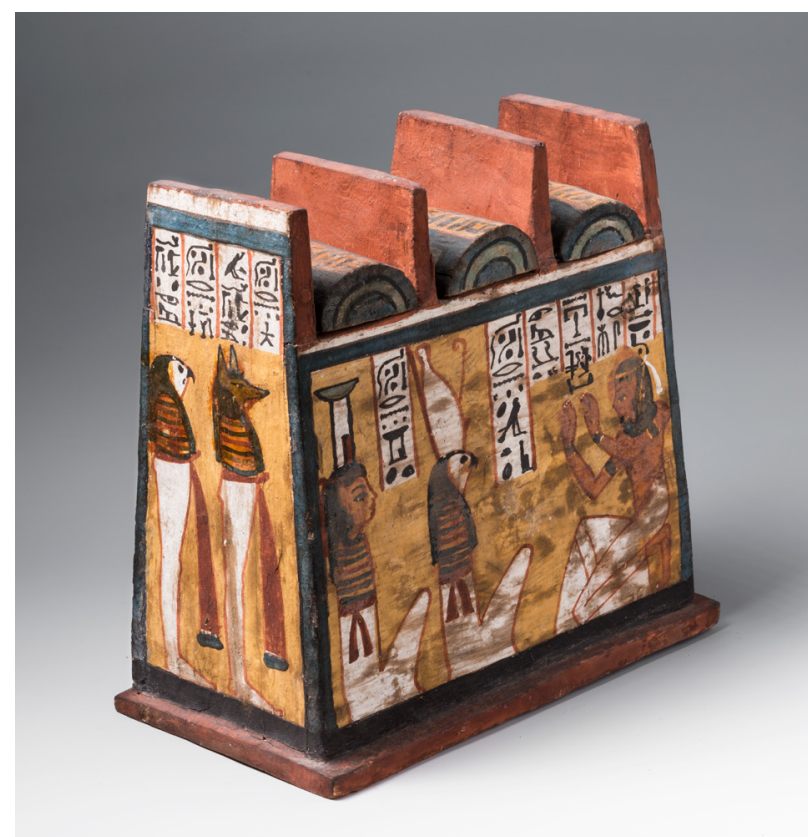

Fig. 1: Shabti-box of Nefermesi (Turin Cat. 2445), Twentieth Dynasty. H. $30 \mathrm{~cm}$. Photo by Nicola Dell'Aquila/Museo Egizio. $\mathrm{cm}$ - which do not match those given by Vidua.

The entry for box *312 gives only a very short description, specifying the object's morphology - "à une seule division" - and that it has a polychrome decoration. Among the boxes conserved in Turin, two may correspond to this description: the shabti-box of Nebhepet (Cat. 2435) ${ }^{13}$ and that of Djehutyhotep (Cat. 2443). The box of Nebhepet, even though belonging to the type with one $p r-n w$ chapel, has a very different decoration than the previous two. Its front side is decorated with the false-door motif (Fig. 3), while the other sides show a texture imitating woodgrain. ${ }^{14}$ Furthermore, the tops of the two short sides - forming jambs rising above the box - are graced with the head of a sparrowhawk. Box Turin Cat. 2443, on the contrary, is very similar to the above-mentioned and illustrated coffer of Nia (Cat. 2444), especially in the representation of relatives worshipping their dead ancestors and the decorative polychrome strips, with geometric motifs reproducing a false-door on the bottom and, on the top, floral motifs of blue lotus petals. It therefore seems more likely that this is the box described under number *312 in Vidua's list. The iconography described above makes the links among the three objects seem stronger: we note that, in the list entries, the items are distinguished primarily on the basis of morphology, with little mention of decoration.

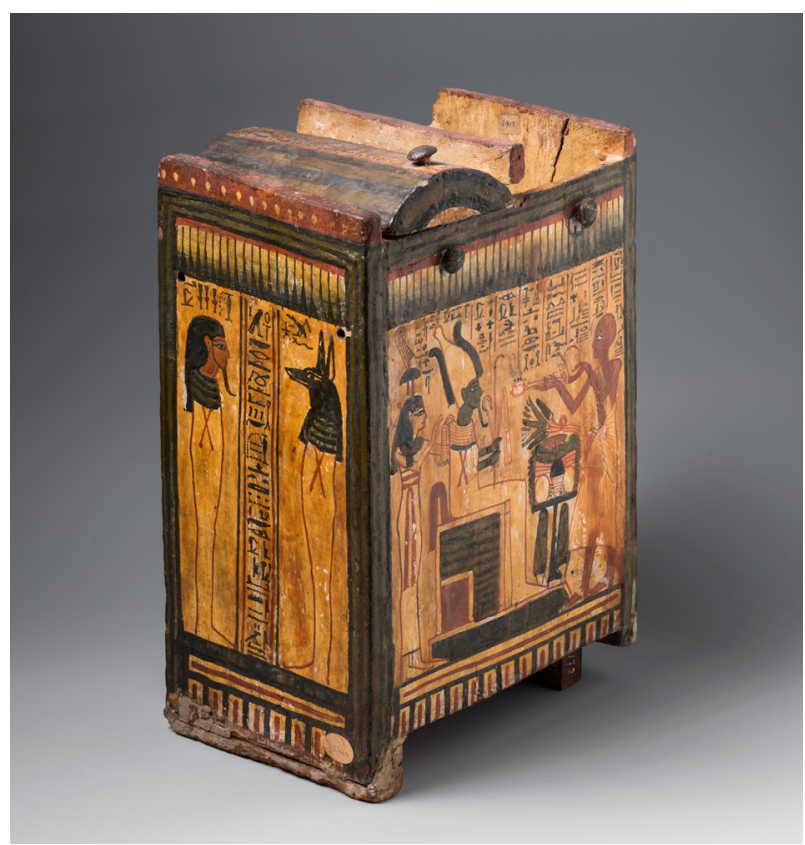

Fig. 2: Shabti-box of Nia (Turin Cat. 2444), Nineteenth Dynasty. H. 30,5 cm. Photo by Nicola Dell'Aquila/Museo Egizio. 


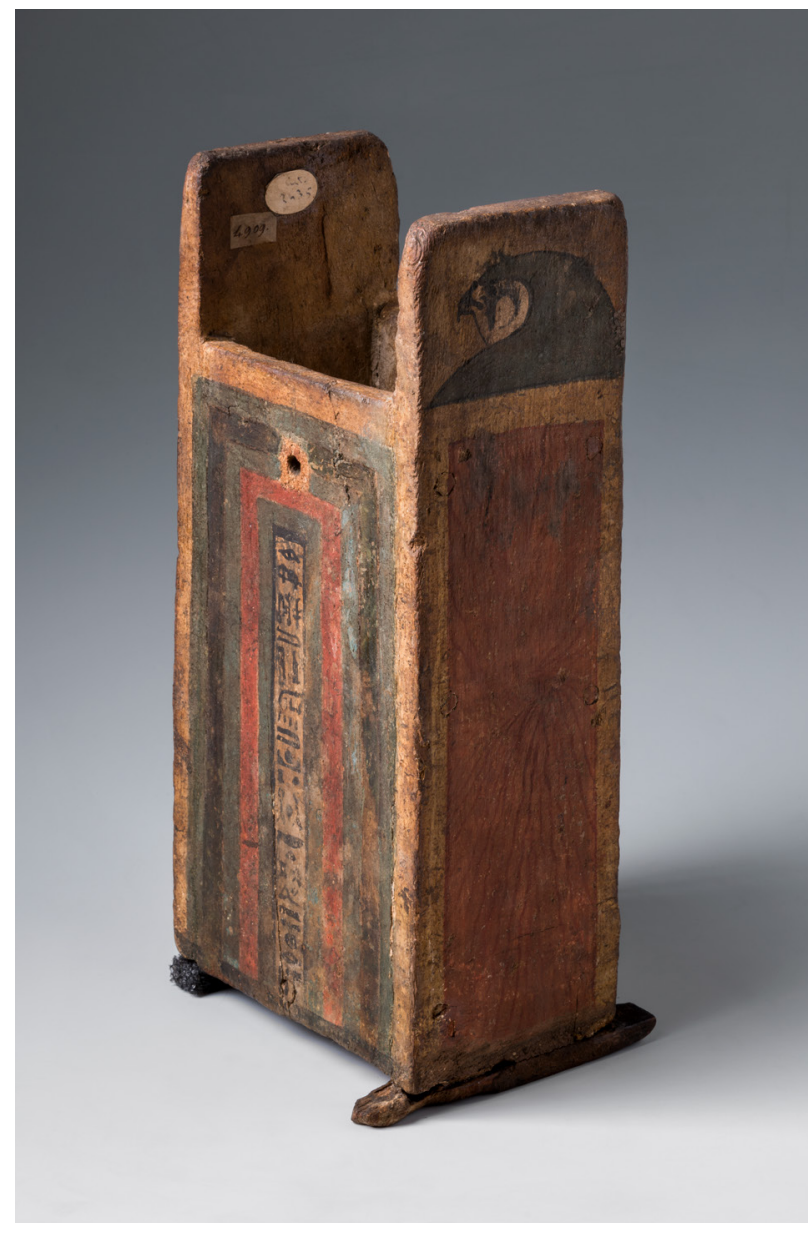

Fig. 3: Shabti-box of Nebhepet, Twentieth Dynasty, (Turin Cat. 2435). Photo by Nicola Dell'Aquila/Museo Egizio.

\section{Description}

Djehutyhotep's shabti-box is a plastered and painted wooden box, $31.5 \mathrm{~cm}$ tall and $16 \times 14.2 \mathrm{~cm}$ in plan. ${ }^{15}$ It rests on a protruding base and culminates in two lateral jambs, between which a vaulted lid is set. On the front of the box and on the corresponding side of the lid are two button-shaped knobs. They were used to fasten the lid by means of a now lost string. The box resembles a Predynastic $p r-n w$ chapel in shape. Its surface is entirely covered by a thin plaster layer - relatively well preserved with some losses here and there - on which brightly colored funerary scenes are painted.

The front side (Fig. 4) is almost entirely occupied by the representation of a masculine figure, facing rightwards, sitting on a chair with a high backrest and lion-paw feet. He is wearing sandals, a white pleated robe knotted at the belly with very wide sleeves, a wesekh collar, some green bracelets and a “double wig”. The figure wears a goatee and drinks from a cup held in the right hand. The left hand is raised in a gesture of devotion. The cup is filled by a stream of water coming from a hes vase, held by a female figure whose body rises from the branches of a tree in front of the male figure. A second stream of water, coming from the same hes vase, fills a second cup placed under the chair. From this cup a human-headed bird drinks. The scene represents the dead person and his ba drinking the purifying water poured by the sycamore tree goddess (Fig. 4).

On the right side (Fig. 5), the owner of the box is represented as a mummy on a pedestal, facing left towards an offering table beyond which is a bouquet. He is wrapped in white bandages and wears a wesekh collar. He wears a goatee and a "double wig” surrounded by a yellow band. An ointment cone rests on the wig.

The back is less well preserved, but the decoration is still clearly visible. The scene is dominated by the standing figure of the owner, dressed as he would have been when alive: elegant sandals on his feet, an elaborate garment with wide sleeves, gathered at the waist, and a double wig. He wears a wesekh collar and bracelets, and holds a flabellum in his left hand. A second male figure is aspersing him with purifying water issuing from a hes vase. This figure has a shaved head and wears a short white pleated robe and a leopard skin on the shoulders, the typical attire of the sem priest. Even though no caption specifies the identity of this second individual, it might be one of the sons of Djehutyhotep, since this kind of scene typically depicts the worship of dead ancestors (Fig. 6).

The left side shows a scene divided in two by a central column of hieroglyphs, featuring two mummiform figures, facing one another. They wear a large wesekh collar, a tripartite wig and false beard with well-visible black lines connecting it to the ears. In front of each figure is a bouquet extending from the feet to the knees. Hieroglyphic captions at the top of the scene identify the figures as Amset and Hapi, respectively on the right and left (Fig. 7).

The four scenes are clearly inspired by wall paintings in Theban tombs of the New Kingdom. ${ }^{16}$ The scenes are graced by polychrome borders with geometrical and floral motifs; the one below reproduces a stylized false-door motif, the one above a row of blue lotus petals. 


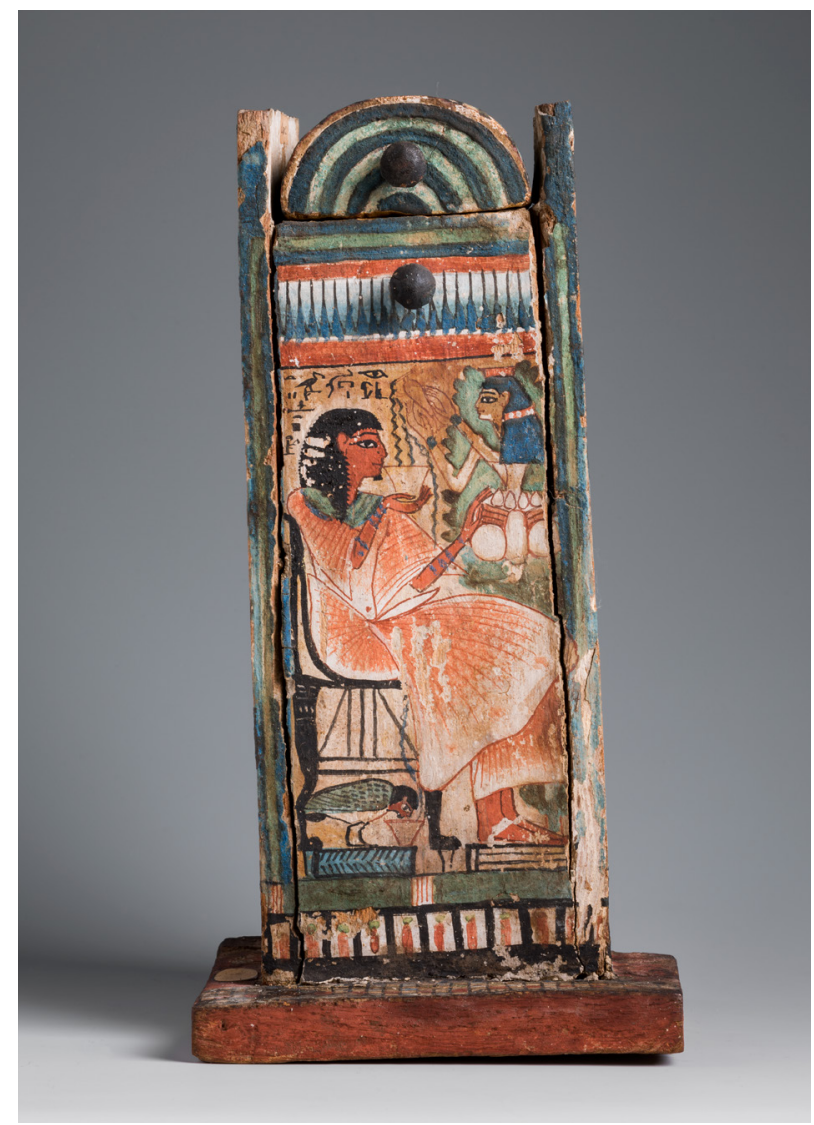

Fig. 4: Shabti-box of Djehutyhotep (Turin Cat. 2443), front. H. 31,5 cm. Photo by Nicola Dell'Aquila/Museo Egizio.

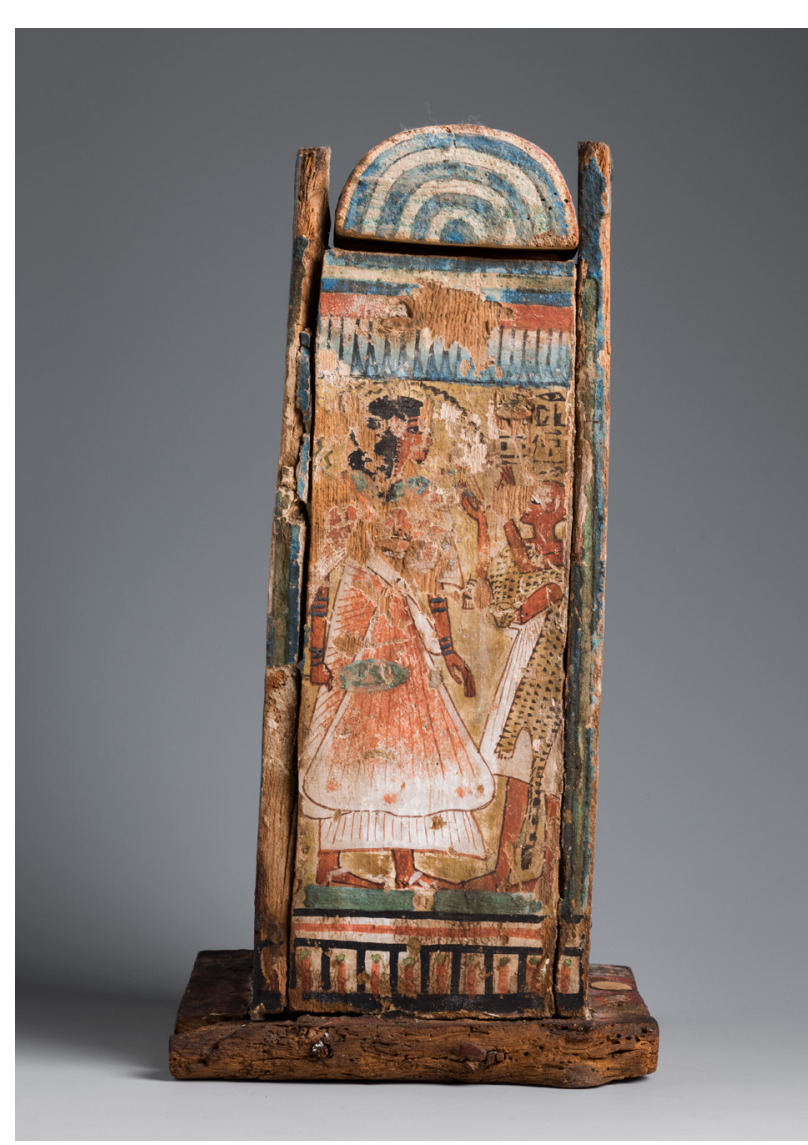

Fig. 6: Shabti-box of Djehutyhotep, back. Photo by Nicola Dell'Aquila/Museo Egizio.

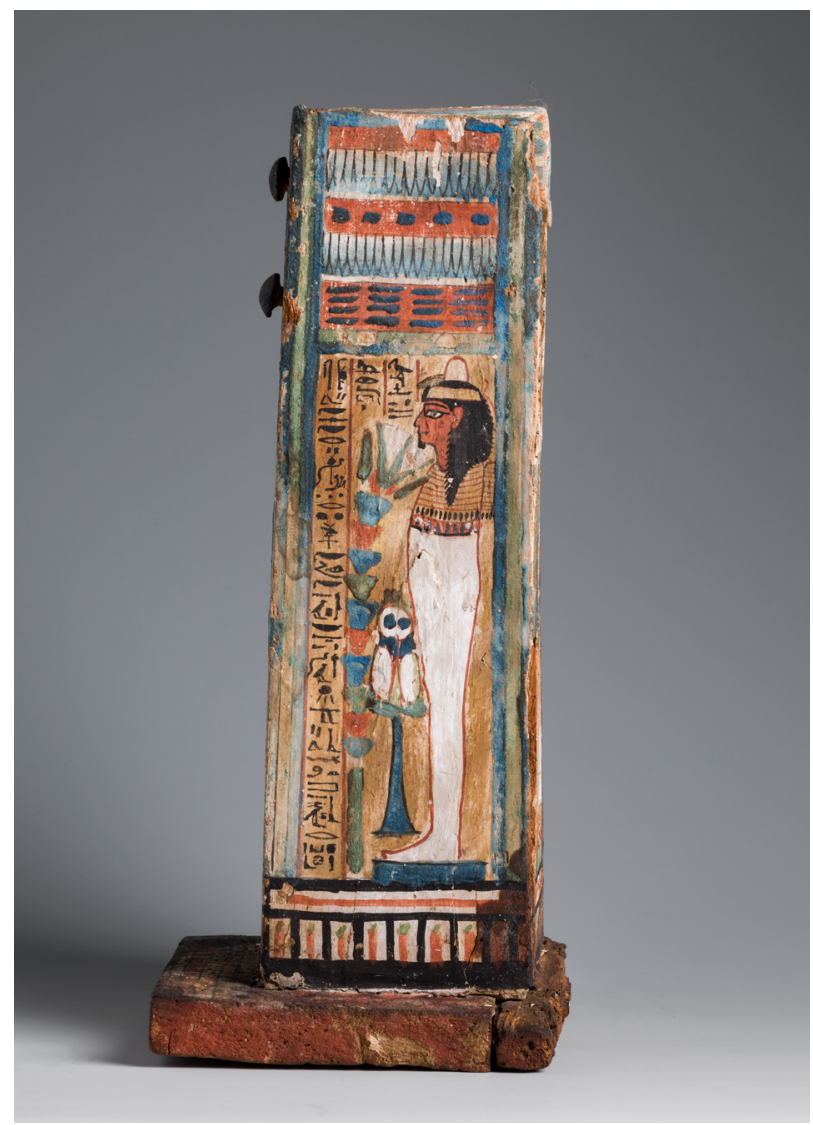

Fig. 5: Shabti-box of Djehutyhotep, right side. Photo by Nicola Dell'Aquila/Museo Egizio.

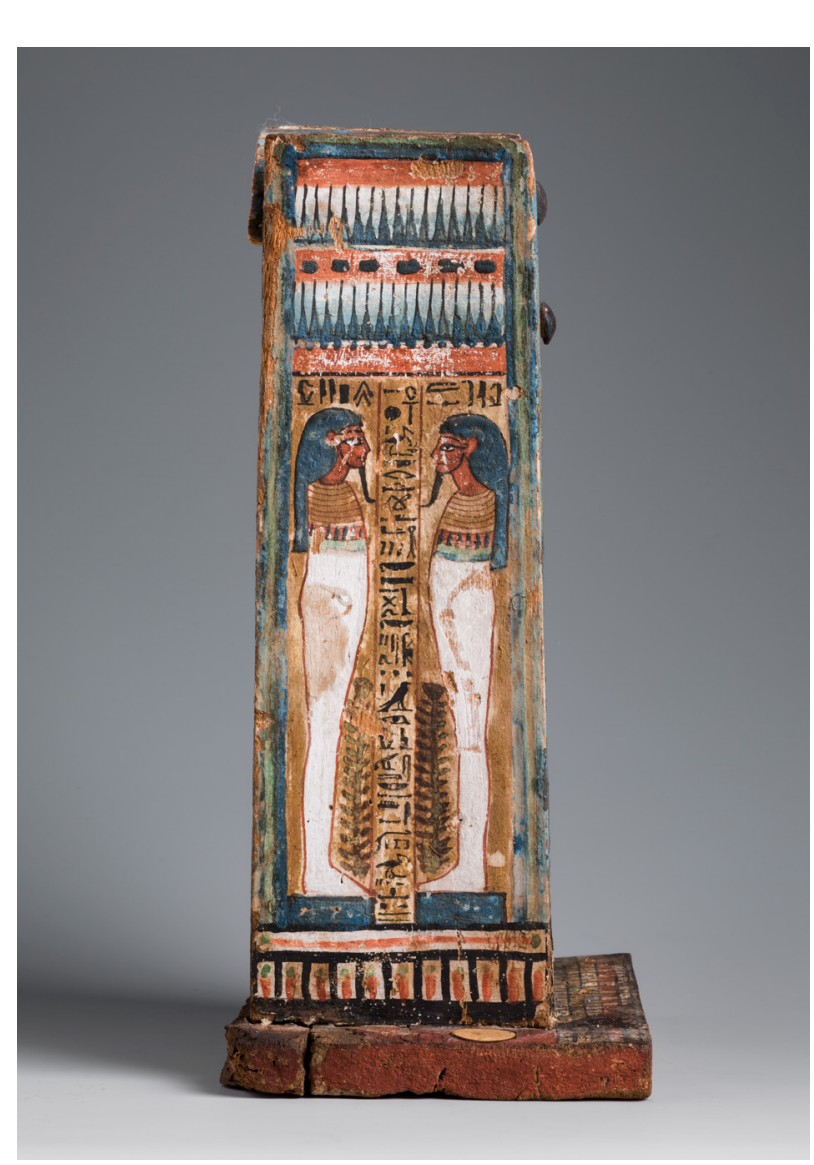

Fig. 7: Shabti-box of Djehutyhotep, left side. Photo by Nicola Dell'Aquila/Museo Egizio. 


\section{Inscriptions}

The walls of shabti-box Cat. 2443 are inscribed with columns and rows of very well-preserved hieroglyphs, ${ }^{17}$ written confidently and steadily in black ink. When the text is not limited to a mere caption, but also mentions names and titles of the figures represented in the scenes, it eulogizes the dead or evokes some typical funerary rituals of the Theban area.

Front:

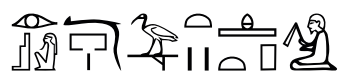

Wsjrjmy-r pr ${ }^{18}$ Dhwty-ḥtp

The Osiris, the steward Djehutyhotep

Left side:

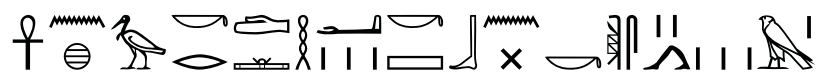

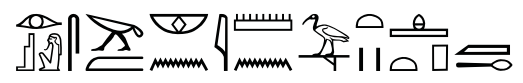

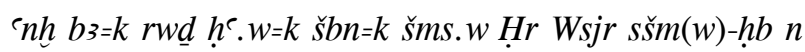
Jmn jmy-r pr Dhwty-htp mз $3^{r}-h r w$

May your $b a$ live, may your limbs be strong. May you join ${ }^{19}$ the followers of Horus. ${ }^{20}$ The Osiris, the leader of the festival of Amun, the steward Djehutyhotep, justified.

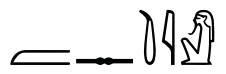

Jmstj

Amseti

Back:

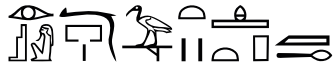

Wsjr jmy-r pr D Dhwty-htp mз $3^{\top}-h r w$

The Osiris, the steward Djehutyhotep

Right side:

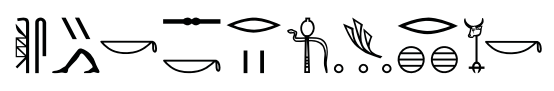

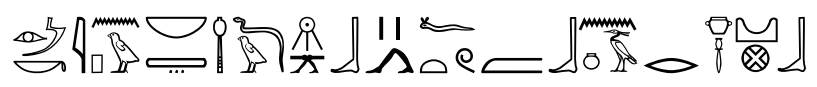

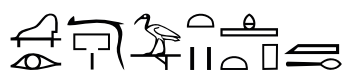

$\check{s} m s=k S k r h \underline{d} \underline{d} w r h \underline{h}=k m_{33}=k J n p w n b t 3-h \underline{d}^{21} s b i=f t w m$ bnw $r$ з $b \underline{d} w$ Wsjr jmy-r pr Dḥty-htp mз $3^{c}-h r w$

May you follow Sokar, onions being round your neck, may you see Anubis, lord of the Land of Dawning, ${ }^{22}$ while he leads you as a heron to Abydos. The Osiris, the steward Djehutyhotep.

Lid:

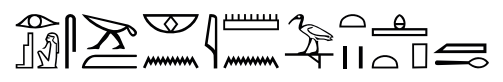

Wsjr sšm(w) ḥb n Jmn Dhhwty-ḥtp m3-ḩrw

The Osiris, leader of the festival of Amun, Djehutyhotep, justified

Among these many inscriptions the most interesting is the one on the right side. It refers to the god Sokar, to the ritual use of onion and to the journey of the dead to Abydos. These three elements are related to a funerary rite attested during the New Kingdom. The rite was carried out in the night between the $25^{\text {th }}$ and the $26^{\text {th }}$ of Khoiak, on the west bank at Thebes. It was related to the $n t r j t^{23}$ festival, more specifically to the invigoration of the mummy of the god Sokar-Osiris and to the procession on board a boat to the Temples of Millions of Years and to the necropolis. ${ }^{24}$ During that night, privately, the $k a$-priests and/or the kinsmen of the Theban dead carried out rites of libation or purification in the chapels of the tombs. They wore necklaces made of braided onions and offered them to Sokar and to the dead. ${ }^{25}$ The previous two nights of the $23^{\text {rd }}$ and $24^{\text {th }}$ of Khoiak were devoted to the embalming of the statue of Sokar-Osiris, the rite of the opening of the mouth, and the protection of the mummy, which, being one with Osiris, sailed on the nšmt-boat to Abydos, where the deceased became $m_{3}{ }^{r}-h r w{ }^{26}$

Onion was much used in Egypt, where it was grown since ancient times. It is mentioned in the Pyramid Texts, where it is designated by the word $h \underline{d} w w^{27}$ It was used in various contexts, for example in medicine-magic, ${ }^{28}$ especially against the bites of snakes and scorpions. ${ }^{29}$ Its antiseptic properties were much appreciated. During the process of mummification, it was placed on the chest and the upper belly, and in the facial cavities (mouth and eyes). ${ }^{30}$

\section{Dating}

The morphological features of the shabti-box of Djehutyhotep place it among the shabti-boxes of Type Marini I (Aston Type II), dated to between the middle and the end of the Eighteenth Dynasty. ${ }^{31}$ Nevertheless, the scenes decorating it - representing the dead 
man in the presence of his ancestors, the sycamore tree goddess and his $b a$ - and the elaborate borders with lotus flower petals and the false-door motif are closer in style and subject matter to the boxes of the "Marini IIb and IIIa” types (Aston Type II and IV, respectively), featuring double and triple $p r-n w$ chapels and dated between the mid-Nineteenth and the Twentieth Dynasties. ${ }^{32}$ Even though the morphology of shabti-boxes is typically crucial in determining their typology and dating, in this case it has less diagnostic value. Indeed, reuse of canonical artistic forms from the Eighteenth Dynasty is commonly attested during the Nineteenth and Twentieth Dynasties. ${ }^{33}$ The choice of specific subjects such as the sycamore tree goddess and the $b a$, on the contrary, constitutes a more certain terminus post quem: the two subjects are, indeed, widely attested in the wall paintings of Theban tombs and on shabti-boxes. The representation of the sycamore tree goddess is clearly inspired by Chapter 59 of the Book of the Dead; although the scene is attested on the walls of some tombs of the Eighteenth Dynas- $\mathrm{ty}^{34}$ it becomes popular only in the Ramesside age, ${ }^{35}$ when it also enters the iconography of shabti-boxes. ${ }^{36}$ The representation of the $b a$ is also first attested on the walls of Theban tombs of the Eighteenth Dynasty , but is more widespread in the Ramesside age. ${ }^{37}$ In particular, the theme of the $b a$ drinking the water poured by the sycamore tree goddess is seen only from the Nineteenth Dynasty onward, both in wall paintings $^{38}$ and on coffers. ${ }^{39}$ Moreover, another element suggesting a date no earlier than the Nineteenth Dynasty for the box is the two polychrome strips, with false-door motifs below and lotus-flower petals above. This feature can be seen on several double $p r$ $n w$ chapel-shaped shabti-boxes, possibly dating to the Nineteenth ${ }^{40}$ and Twentieth Dynasties. ${ }^{41}$

\section{The shabti-box of the royal scribe, chief steward of the Southern City and leader of the feast of Amun-Re Djehutyhotep}

Djehutyhotep, the owner of shabti-box Turin Cat.
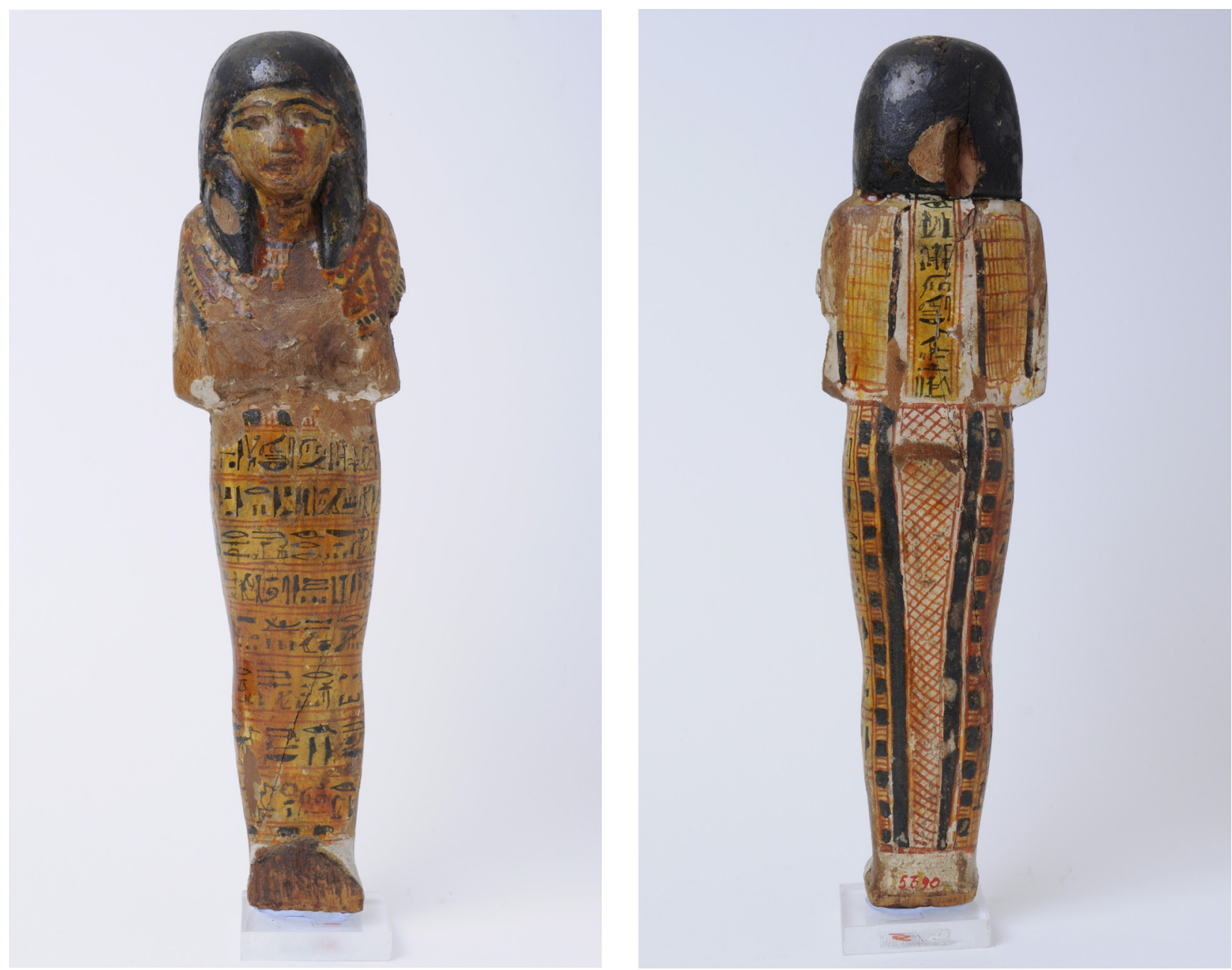

Fig. 8: Shabti of Djehutyhotep II (Trieste 5390). H. 28,5 cm. Photo by Enrico Halupca/Civico Museo di Storia e Arte in Trieste. 


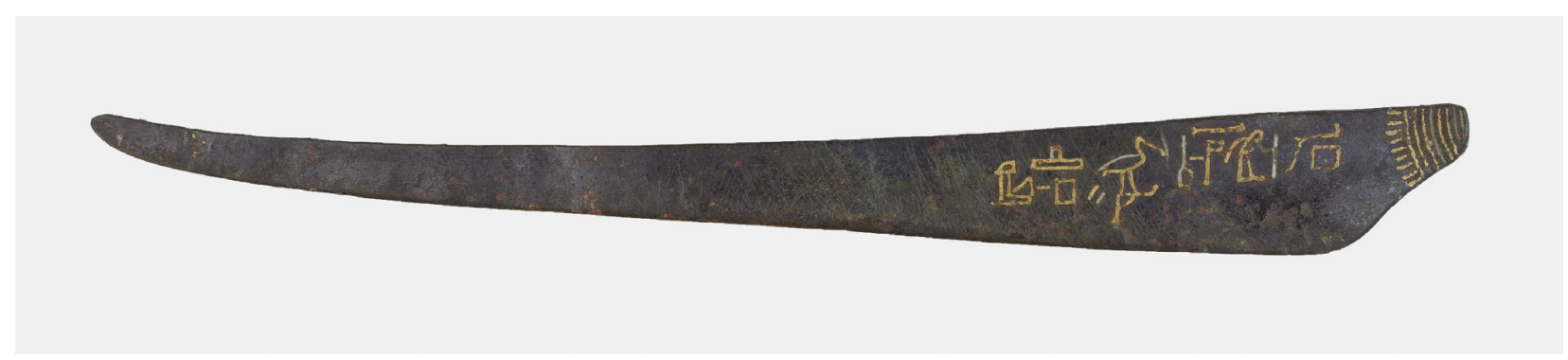

Fig. 9: Knife of Djehutyhotep I (The Met 48.105.3). L. 14 cm. Photo public domain, CCO 1.0.

2443, bears the titles of jmy-r pr (steward) and $s \check{\text { - }}$ $m(w)-h b n$ Jmn-Re (leader of the feast of Amun-Re). Both the name and the titles suggest that he is the same Djehutyhotep who owned a shabti in the Civico Museo di Storia e Arte in Trieste (Inv. no. 5390, Fig. 8), ${ }^{42}$ inscribed with the following titles:

$s \check{s} n s w t=$ royal scribe;

jmy-r pr wr $n$ niw.t-rs.t = chief steward of the Southern City;

$s \check{m}(w)-h b n$ Jmn-R ${ }^{c}=$ leader of the feast of Amun-Re.

Claudia Dolzani dates this statuette to the end of the Eighteenth Dynasty on stylistic and typological grounds. ${ }^{43}$ Franco Crevatin reminds us that Wolfgang Helck - in Zur Verwaltung des Mittleren und Neuen Reichs -, also attributes the blade of a bronze knife (Fig. 9) kept in the Metropolitan Museum of New York (n. inv. 48.105.3) and the head of a granite statue (Fig. 10) in the Ny Carlsberg Glyptotek (Copenhagen EIN 1019) to the owner of shabti Trieste 5390. ${ }^{44}$ Both the knife and the head are attributable to a famous Djehutyhotep ${ }^{45}$ who lived during the reign of Hatshepsut. The bronze blade was found by the archeological mission of the Metropolitan Museum near the funerary temple of Hatshepsut in Deir el-Bahari. ${ }^{46}$ Close to the junction between the blade and the now lost handle - probably originally of wood - is the inscription: jmy-r pr $n$ ntr-nfr Dhwty-hitp = steward of the good god, Djehutyhotep. Hayes attributes it to the same Djehutyhotep as the owner of the Copenhagen statue. ${ }^{47}$ The head of the granite statue belongs to a type with a back-pillar, smooth wig, and short beard. It has pierced earlobes and shaded eyebrows ${ }^{48}$ and it bears the titles jmy-r pr š̌mw ḥb n Imn Dḥwty-htp (chief steward, leader of the feast of the god Amun, Djehutyhotep). Otto Koe-
foed-Petersen dated it between the Eighteenth and Nineteenth Dynasties. ${ }^{49}$ Furthermore, pierced earlobes appear on depictions of men in the last decade of the reign of Amenhotep III and then became very popular during the Amarna period and later. ${ }^{50}$ Shaded eyebrows also became common towards the end of the reign of Horemheb. ${ }^{51}$ Finally, the mouth is of a shape found on statues of the Ramesside period. All these data thus do not support Helck's attribution, but rather point to a date between the end of the Eighteenth and the early Nineteenth Dynasty. Moreover, the British Museum has a small vaulted wooden lid with a semicircular section, a more or less square base, a knob on the front lunette and a column of hieroglyphs on the top (Fig. 11) reading $s \check{s}$ nswt jmy-r pr wr m njw.t-rs.t sšm(w)-ḥb n Jmn-Re Dhwwty-htp (royal scribe, chief steward of the Southern City [=Thebes], leader of the feast of Amun-Re, Dje-

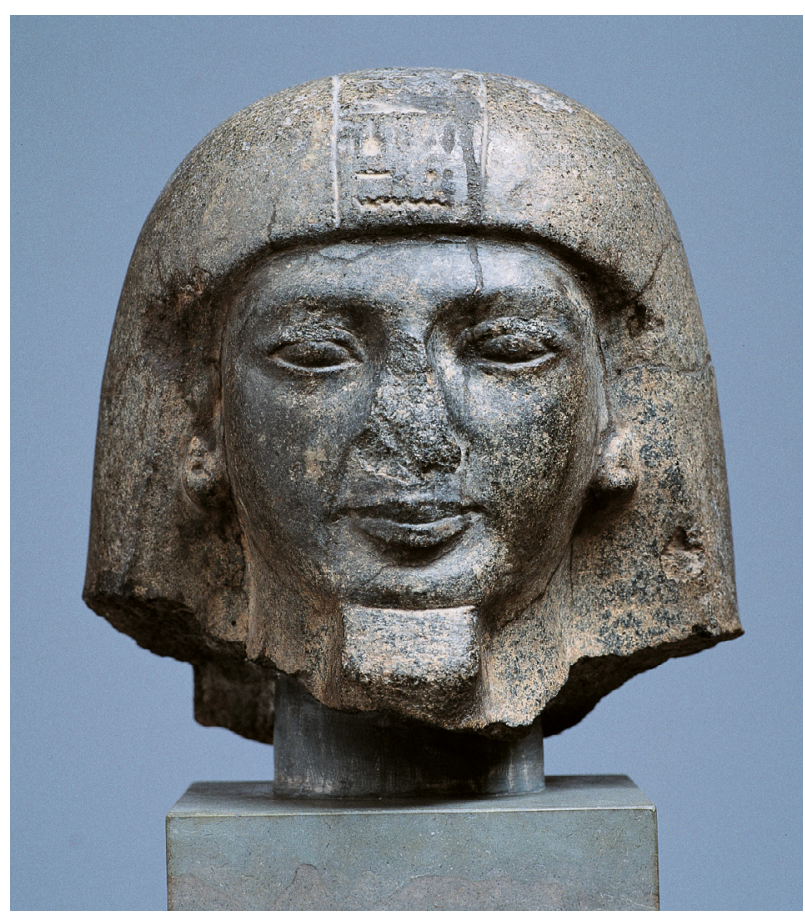

Fig. 10: Head of a statue of Djehutyhotep (Copenhagen, Ny Carlsberg Glyptotek, ÆIIN. 1019). H. 25 cm. Photo by Ole Haupt. 
hutyhotep [BM EA 30801]). ${ }^{52}$ The shape, the dimensions $(9.3 \times 8.6 \mathrm{~cm})$ and the knob on the lunette suggest that it is a lid for a single $p r-n w$ chapel-shaped shabti-box, datable to the Eighteenth Dynasty. ${ }^{53}$ The closest parallel is indeed the lid of a shabti-box of an Amenemhat (New York, Brooklyn Museum 50130a-

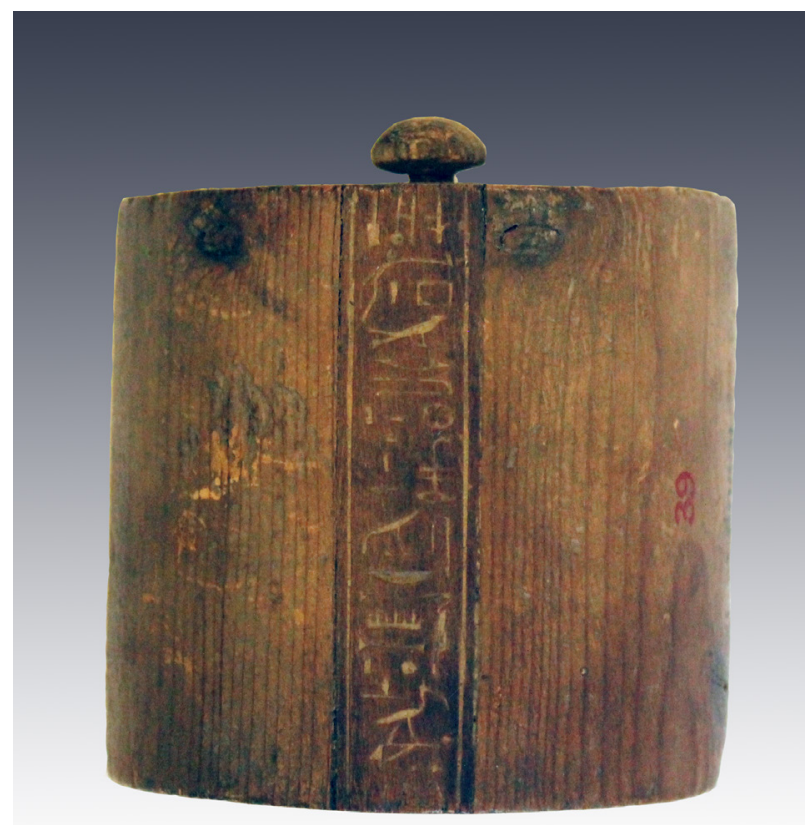

Fig. 11: Shabti-box lid of Djehutyhotep (BM EA 30801). H. 3.56 cm, I. 9.03 cm, w. 8.06 cm. Photo by Paolo Marini.

b) dated to the reign of Thutmosis IV. ${ }^{54}$

The homonymy and the sameness of the title on all the above objects suggest that they might all belong to the same owner. However, their stylistic dating does not support this hypothesis. Indeed, knife blade New York 48.105.3 and shabti-box lid London BM EA 30801, as we have seen, date from the Eighteenth Dynasty. Statue head Copenhagen ÆIN 1019, instead, can be dated between the end of the Eighteenth and the early Nineteenth Dynasty, and shabti-box Turin Cat. 2443 cannot be earlier than the Nineteenth Dynasty. A later date can also be suggested for shabti Trieste 5390, which shows elements such as the painted layered wig and other stylistic details that are typical of the Ramesside age and earlier.

In the light of the above, then, the objects must in fact belong to at least two homonymous individuals: one who lived in the age of Hatshepsut (Djehutyhotep I) and another who lived in the late Eighteenth to early Nineteenth Dynasty (Djehutyhotep II). Further support for this hypothesis can be found in a stylistic comparison between three of the five objects, namely, shabti-box lid London BM EA 30801, shab-

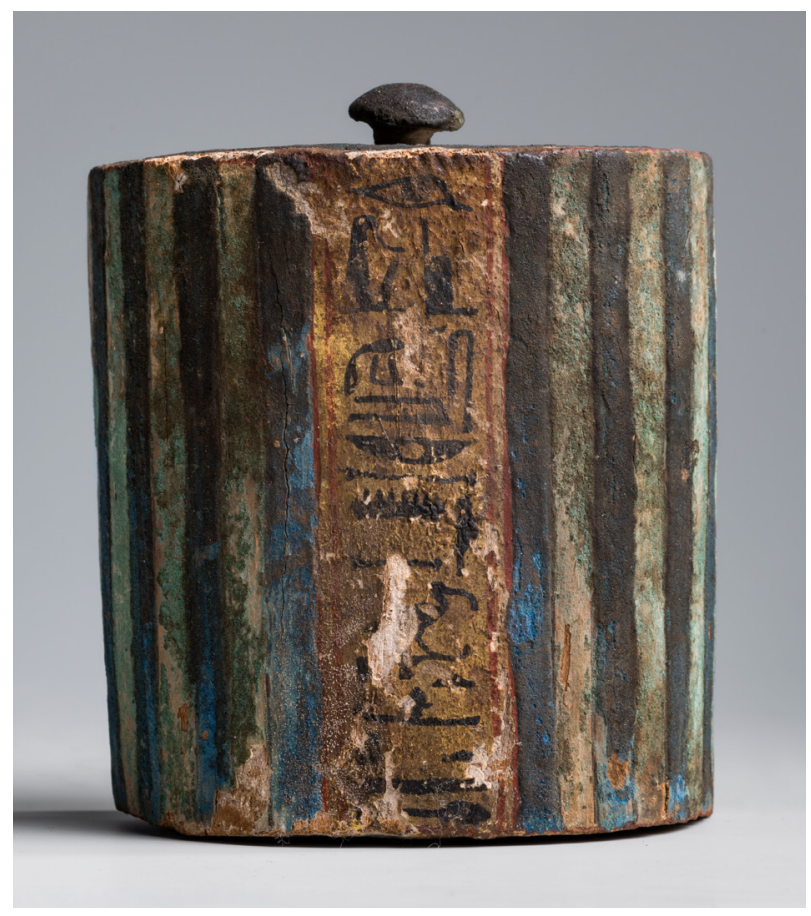

Fig. 12: Shabti-box lid of Djehutyhotep (Turin Cat. 2443). H. 4 cm, I. 9 cm, w. 8.4 cm. Photo by Nicola Dell'Aquila/ Museo Egizio.

ti-box Turin Cat. 2443 (Fig. 12) and shabti Trieste 5390. Three objects from the same funerary assemblage should surely resemble one another. Instead, the lid in the British Museum piece is very different in style from the shabti-box in Turin and the shabti in Trieste, most notably because it is unpainted, whereas both of the latter objects carry a fine pictorial decoration.

Shabti-box Turin Cat. 2443, as the decoration suggests, was thus probably made during the reign of Ramesses II for an eminent official who lived and was buried in the Theban area. The object is a very interesting and rare example of its kind: it has the usual decoration of shabti-boxes of Type Marini IIIa (Aston Type IV) but the morphology of shabti-boxes of Type Marini I (Aston Type II). Indeed, it does not seem to fit into any existing typological slot. 
Table 1: Complete list of the shabti-containers of the Museo Egizio of Turin

\begin{tabular}{|c|c|c|c|c|c|c|}
\hline & Container & Material & Inventory number & $\begin{array}{l}\text { Name } \\
\text { of the deceased }\end{array}$ & Typology & Dating \\
\hline 1 & Box & Wood & Cat. 2444 & $\mathrm{Nia}$ & IIC & Ramesses II \\
\hline 2 & Box * & Wood & Cat. 5199 & Nefertari & $?$ & ? \\
\hline 3 & Box & Baked clay & Cat. 3453 & - & IIC & Nineteenth Dynasty \\
\hline 4 & Box & Baked clay & Cat. 3454 & Pakharu & - & Nineteenth Dynasty \\
\hline 5 & Box & Baked clay & Cat. 3455 & - & - & Nineteenth Dynasty \\
\hline 6 & Box & Wood & Cat. 2443 & Djehutyhotep II & IIC & Nineteenth Dynasty \\
\hline 7 & Box & Wood & Cat. 2434 & Amenemope & Variant II & Nineteenth Dynasty \\
\hline 8 & Vase & Baked clay & Cat. 3485 & Khay & $\mathrm{A}$ & Nineteenth Dynasty \\
\hline 9 & Vase & Baked clay & Cat. 3487 & - & A & Nineteenth Dynasty \\
\hline 10 & Vase & Baked clay & Cat. 3488 & Isi & $\mathrm{A}$ & Nineteenth Dynasty \\
\hline 11 & Vase & Baked clay & Cat. 3489 & Nashuyu & $\mathrm{A}$ & Nineteenth Dynasty \\
\hline 12 & Vase & Baked clay & Cat. 3490 & Takhesha & $\mathrm{A}$ & Nineteenth Dynasty \\
\hline 13 & Vase & Baked clay & Cat. 3491 & Neheh & $\mathrm{A}$ & Nineteenth Dynasty \\
\hline 14 & Vase & Baked clay & Cat. 3492 & Isi & $\mathrm{A}$ & Nineteenth Dynasty \\
\hline 15 & Vase & Baked clay & Cat. 3493 & Amenhat & $\mathrm{A}$ & Nineteenth Dynasty \\
\hline 16 & Vase & Baked clay & Cat. 3494 & - & $\mathrm{A}$ & Nineteenth Dynasty \\
\hline 17 & Vase & Baked clay & Cat. 3495 & Nay & $\mathrm{A}$ & Nineteenth Dynasty \\
\hline 18 & Vase & Baked clay & Cat. $3496^{58}$ & Djehutymes & $\mathrm{A}$ & Nineteenth Dynasty \\
\hline 19 & Vase & Baked clay & Cat. $3497^{59}$ & Perkhemenu & $\mathrm{A}$ & Nineteenth Dynasty \\
\hline 20 & Vase & Baked clay & Cat. $3498^{60}$ & Meh & $\mathrm{A}$ & Nineteenth Dynasty \\
\hline 21 & Vase & Baked clay & Cat. 3499 & Mesmen & $\mathrm{A}$ & Nineteenth Dynasty \\
\hline 22 & Vase & Baked clay & Cat. $3500 / 2^{*}$ & - & $\mathrm{A}$ & Nineteenth Dynasty \\
\hline 23 & Vase & Baked clay & Cat. $3500 / 3^{*}$ & - & $\mathrm{A}$ & Nineteenth Dynasty \\
\hline 24 & Vase & Baked clay & Cat. 3502 & - & $\mathrm{A}$ & Nineteenth Dynasty \\
\hline 25 & Vase & Baked clay & Cat. 3504 & - & $\mathrm{A}$ & Nineteenth Dynasty \\
\hline 26 & Vase & Baked clay & Cat. 3533 & Pakharu & $\mathrm{A}$ & Nineteenth Dynasty \\
\hline 27 & Vase & Baked clay & Cat. 3542 & - & $\mathrm{A}$ & Nineteenth Dynasty \\
\hline 28 & Vase & Baked clay & Provv. 5650 & - & $\mathrm{A}$ & Nineteenth Dynasty \\
\hline 29 & Box & Wood & Provv. 260 & Tahesibehed & IIIa & $\begin{array}{l}\text { Nineteenth/Twentieth } \\
\text { Dynasty }\end{array}$ \\
\hline 30 & Box & Wood & Cat. 2435 & Nebhepet & Variant II & Twentieth Dynasty \\
\hline 31 & Box & Wood & Cat. 2445 & Nefermesi & IIIa & Twentieth Dynasty \\
\hline 32 & Box & Wood & Cat. 2430 & Patjauemditamun & IV & Twenty-First Dynasty \\
\hline 33 & Box & Wood & S. 905 & - & VIc & Twenty-First Dynasty \\
\hline 34 & Box & Wood & Provv. 729 & $?$ & VIIa & Tenth/ninth cent. BC \\
\hline 35 & Box & Wood & Cat. 2440 & Pep & VIIb & Seventh cent. BC \\
\hline 36 & Box & Wood & Cat. 2441 & Pep & VIIb & Seventh cent. BC \\
\hline 37 & Box & Wood & Provv. 3296 & Ur & VIIC & Twenty-Fifth Dynasty \\
\hline 38 & Box & Wood & Provv. 728 & $?$ & VIIc & Twenty-Fifth Dynasty \\
\hline 39 & Box & Wood & Provv. 727 & Tjaienhotepet & VIIC & Twenty-Fifth Dynasty \\
\hline 40 & Box & Wood & Cat. 2437 & Paiuiu & VIIc & Twenty-Fifth Dynasty \\
\hline 41 & Box & Wood & Provv. 726 & $\begin{array}{l}\text { Namenekhamene- } \\
\text { mope }\end{array}$ & VIIc & Twenty-Fifth Dynasty \\
\hline 42 & Box & Wood & Cat. 2439 & Harsiesi & VIIIa & Seventh cent. BC \\
\hline 43 & Box & Wood & Provv. 721 & Usirhor & VIIIb & Seventh cent. BC \\
\hline 44 & Box & Wood & Cat. 2451 & Pentjenef & VIIIb & Seventh cent. BC \\
\hline 45 & Box & Wood & Provv. 5651 & $?$ & VIIIb & Seventh cent. BC \\
\hline 46 & Box & Wood & Cat. 2438 & Nayeftjaurudj & VIIIb & Seventh cent. BC \\
\hline
\end{tabular}




\section{Endnotes}

${ }^{1}$ Fabretti et al., Regio Museo di Torino, p. 346.

${ }^{2}$ Moiso, La storia del Museo Egizio, p. 44.

${ }^{3}$ Especially in the area of the temples and the necropolis of Thebes. See Moiso, Museo Egizio, p. 40.

${ }^{4}$ The shabti-box has never been deeply studied, even though it has often been listed or briefly described. See: Marini, I contenitori di ushabti, pp. 53, 64, 292, table 3, figs. 19-20; Marini, EVO 35 (2012), pp. 89-90; Donatelli, in Donadoni Roveri, (ed), Civiltà degli Egi$z i$. Le credenze religiose, pp. 204, 206; Maspero, RT IV (1882), p. 151; Fabretti et al., Regio Museo di Torino, p. 346; Orcurti, Catalogo illustrato, p. 106.

5 [Vidua], in Documenti inediti, p. XII.

${ }^{6}$ [Vidua], in Documenti inediti, pp. 206-92.

${ }^{7}$ [Vidua], in Documenti inediti, pp. 235-48.

${ }^{8}$ Shabti-boxes in the shape of a Pre-dynastic $p r-n w$ chapel - very simple buildings made of light material, such as mud bricks or perhaps trellis, consisting of a chamber covered by a barrel-shaped vault or by a dome of reeds and rushes (Hayes, The Scepter of Egypt, II, p. 448) - were produced in Egypt beginning in the mid-Eighteenth Dynasty, continuing until the Twenty-First Dynasty. Marini, EVO 35 (2012), p. 86.

${ }^{9}$ Marini, I contenitori di ushabti, pp. 74, 83, 84, 198, 292; Marini, EVO 35 (2012), pp. 96: figs. 11, 97; Orcurti, Catalogo illustrato, p. 106, n. 197; Fabretti et al., Regio Museo di Torino, p. 347; Seipel, Ägypten: Götter, Gräben und die Kunst, p. 214, n. 197; pp. 213-214, table 196; Aston, OMRO 74 (1994), pp. 213-214, no. 196; Humberg, L'Égypte, une description. p. 137, n. 83.

${ }^{10}$ In this article, I use my own typology, which diverges in part from that of Aston (1994). For a parallel, see Marini, EVO 35 (2012), p. 124; for the general features of type “Marini IIIa”, see Marini, EVO 35 (2012), pp. 96-98.

${ }^{11}$ Marini, EVO 35 (2012), p. 96, fig. 11.

${ }_{12}$ Marini, I contenitori di ushabti, pp. 21, 68, 198; Marini, EVO 35 (2012), pp. 93, 95, 122; Guidotti, Il cammino di Harwa, pp. 106, 107, 168, no. 101; Borla, La scuola nell'antico Egitto, p. 27; Aston, OMRO 74, p. 24; Roccati, in L'Egitto fuori dell'Egitto, p. 360; Roccati, Civiltà degli Egizi., p. 144, fig. 193; Habachi, Tavole d'offerta, pp. 55-57, CGT 22047; Habachi, BIFAO 71-72 (1972), pp. 77-79, figs. 6, 7, table 17; Roccati, Itinerari dei $\mathrm{Mu}$ sei e Gallerie Monumenti d'Italia, p. 64, fig. 44; Orcurti, Catalogo illustrato, p. 105, n. 196; Fabretti et al., Regio Museo di Torino, pp. 346-47.

${ }^{13}$ Marini, in Dorn and Polis ; Marini, I contenitori di ushabti, pp. 168, 169: figs. 58, 171, 179, 292; Trapani, in Collombert et al., Aere perennius. Mélanges Vernus, pp. 814-22, table 5a-d; Marini, EVO 35 (2012), p. 88.

${ }^{14}$ Regarding this topic see: Trapani, in Collombert et al., Aere perennius. Mélanges Vernus, pp. 811-24; Marini, in Dorn and S. Polis (eds.), Outside the Box.

${ }^{15}$ At the base.

${ }^{16}$ Regarding paintings in Theban tombs, see Manniche, Lost Ramessid and Post-Ramessid Private Tombs; Manniche, Lost Tombs; Manniche, The Tombs of Nobles at Luxor; Mekhitarian, Egyptian Painting.

${ }^{17}$ Some small lacunae make the reading somewhat uncertain.
${ }^{18}$ Desplancques, L'institution du Trésor en Egypte, p. 454.

${ }^{19} \mathrm{~Wb}$ IV, 440.

${ }^{20}$ See $W b$ IV, 485.

${ }^{21}$ Kees, ZÄS 71 (1935), pp. 151-55; Habachi, MDAIK 14 (1956), pp. 52-62.

${ }^{22}$ The "Land of Dawning" is the region of Gebelein. See $L \ddot{A}$ I, p. 331. Much more famous is Jnpw nb tz-dsr= Anubis, lord of the sacred earth (necropolis).

Nevertheless, the cult of "Anubis, lord of the Earth that lights up (where it dawns)" is attested together with that of the goddess Hathor at Gebelein. See Habachi, MDAIK 14 (1956), pp. 52-62; AEO, II, p. 20; Kees, ZÄS 71 (1935), p. 150.

${ }^{23}$ Concerning the $n t r j t$ feast, see Posener-Kriéger, Les archives du temple funéraire de Néferirkarê-Kakaï.

${ }^{24}$ Goyon, BIFAO 78 (1978), 415-38.

${ }^{25}$ Graindorge, $R d E ́$ 43 (1992), p. 87.

${ }^{26}$ Graindorge, in Encyclopédie religieuse, p. 325.

${ }^{27}$ Graindorge, in Encyclopédie religieuse, pp. 317.

${ }^{28}$ Graindorge, in Encyclopédie religieuse, pp. 322-25.

${ }^{29}$ Graindorge, in Encyclopédie religieuse, p. 322.

${ }^{30}$ Lucas and Harris, Ancient Egyptian Materials and Industries, p. 316.

${ }^{31}$ Marini, EVO 35 (2012), pp. 86-90.

${ }^{32}$ Marini, EVO 35 (2012), pp. 90-98.

${ }^{33}$ See in particular the shabti-boxes "variant type II": Marini, I contenitori di ushabti, pp. 158-70.

${ }^{34}$ See the tomb of Neferhotep - TT 49 - (PM, I.1, p. 93); the tomb of Neferhotep - TT 50 - (PM, I.1, p. 96); the tomb of Nakht - TT 52 - (PM, I.1, p. 100); the tomb of Sobekhotep - TT 63 - (PM, I.1, p. 125); the tomb of Kenamun - TT 93 - (PM, I.1, p. 191).

${ }^{35}$ Some tombs of the Ramesside age in which the sycamore tree goddess is represented are: TT 1 , TT 2, TT 3, TT 5, TT 6, ТT 7, TT 9, TT 16, ТT 19, TT 23, TT 33 , TT 41 , TT 51 , TT 54 , TT 58 , TT 106 , TT 133 , TT 135 , TT 137 , TT 138 , TT 158 , TT 178 , TT 211 , TT 218. See PM, I.1, passim.

${ }^{36}$ See shabti-boxes of Ashakhet (Macclesfield 1873.77), of Henutmehyt (London BM EA 41551), Leiden L.IX.1, London BM EA 8526, of Tjauenhuy (Bologna KS 1969).

${ }^{37}$ See shabti-box London BM EA 24712 (in: Aston, OMRO 74 [1994], p. 25), shabti-box Wien 960

(in: Aston, $O M R O 74$, p. 26, table 3.4), shabti-box London BM EA 8526 (in: PM I.2, 837; Aston, OMRO 74 [1994], p. 26.

${ }^{38}$ See the tombs of Amenemosis (TT 19, Seti I), Userhat (TT 51, Seti I), Paser (TT 106, Ramesses II), Panehesi (TT 16, Ramesses II), Neferhotep (TT 133, Ramesses III), Thotnefer (TT 158, Ramesses III), Amennakht (TT 218, Nineteenth/Twentieth Dynasty), Nebenmaat (TT 219, Nineteenth/Twentieth Dynasty), Saymiotef (TT 273, Nineteenth/Twentieth Dynasty), Amenemhab (TT 278, Nineteenth/Twentieth Dynasty), Pahemnetjer (TT 284, Nineteenth/ Twentieth Dynasty), Iny (TT 285, Nineteenth/ Twentieth Dynasty), Niay (TT 286, Nineteenth/ Twentieth Dynasty), Pashedu (TT 292, Nineteenth Dynasty), Hatiay (TT 324, Nineteenth/Twentieth Dynasty), Amenemuia (TT 356, Nineteenth Dynasty), Meryptah (TT 387, Ramesses II).

${ }^{39}$ See shabti-boxes London BM EA 41549, EA 41551, 
EA 8526, Leiden L.IX.1.

${ }^{40}$ See shabti-boxes Turin Cat. 2444, BM EA 24711, EA 8554 and EA 41548, EA 41549, Cambridge E.205.1932, Horace A. Owen (private collection), Nantes 2695, Raleigh NCM G.74.19.4/a-h, Pisa 265. These should mostly be dated to the kingdom of Ramesses II.

${ }^{41}$ For example, shabti-boxes Wien_E_INV_960, Liverpool M 11014.

${ }^{42}$ Crevatin and Vidulli Torlo (eds.), La collezione egizia, p. 139-40, with further literature.

${ }^{43}$ Dolzani, Statuina egiziana wšbti, , p. 5.

${ }^{44}$ Helck, Verwaltung, p. 478; Crevatin and Vidulli Torlo (eds.), La collezione egizia del Civico museo di storia ed arte di Trieste, Trieste 2013, pp. 139-40.

${ }^{45}$ Roehrig and Cathleen, Hatshepsut, p. 54.

${ }^{46}$ Hayes, MMAB 7 (2) (1948-1949), pp. 60-63.

${ }^{47}$ The knife was bought by the Metropolitan Museum in 1948, but had been found during the excavations of Edward Rogers in 1923. See Hayes, MMAB 7 (2) (1948-1949), 60-63.

${ }^{48}$ See Koefoed-Petersen, Catalogue des statues, plate 61.

${ }^{49}$ Koefoed-Petersen, Catalogue des statues, p. 30.

${ }^{50}$ The earliest instance known to me of pierced earlobes for men is found in the tomb of Kheruef in Thebes (TT 192).

${ }^{51}$ Connor, Le statue del Museo Egizio, p. 103. I owe these considerations about the iconography, style and dating of statues to the insightful comments of one of my anonymous reviewers, which I gratefully acknowledge.

${ }^{52}$ Marini, I contenitori di ushabti, pp. 34, 51-53, 65, 281, 290, table 1 , figs. $5-7$.

${ }^{53}$ Marini, I contenitori di ushabti, p. 53.

${ }^{54}$ Marini, I contenitori di ushabti, pp. 49, 182, 290; Marini, EVO 35 (2012), pp. 86-87; Aston, OMRO 74 (1994), p. 22; Cooney, BCMA 62 (1975), pp. 229-34; Cooney, BrookMusB 12 (1951), part. 2, pp. 4-6, fig. 3.

\section{Bibliography}

AEO = Gardiner, A., Ancient Egyptian Onomastica, Oxford 1947.

Aston, D.A., “The Shabti-Box: A Typological Study”, in: OMRO 74 (1994), pp. 21-54.

Borla, M., La scuola nell'antico Egitto, Torino 1997. Connor, S., Le statue del Museo Egizio, Modena 2016.

Cooney, J.D., “Equipment for Eternity”, BrookMusB 12/2 (1951), pp. 1-12.

Cooney, J.D., "Some Late Egyptian Antiquities, I: A Shawabti Box", BCMA 62 (1975), pp. 229-39.

Crevatin, F. and M. Vidulli Torlo, (eds.), La collezione egizia del Civico museo di storia ed arte di Trieste, Trieste 2013.

Desplancques, S., L'institution du Trésor en Egypte des origines à la fin du Moyen Empire, Paris 2006.

Dolzani, C., Statuina egiziana wšbti del Civico Museo di Storia ed Arte di Trieste, Trieste 1961.

Donadoni Roveri, A.M., "La Valle delle Regine”, in: A.M. Donadoni Roveri (ed.), Civiltà degli Egizi: le credenze religiose, Milano 1988, pp. 146-61. Donatelli, L., "Piccoli oggetti di corredo funerario nelle varie epoche", in: A.M. Donadoni Roveri, (ed.), Civiltà degli Egizi: le credenze religiose, Milano 1988, pp. 198-211.

Fabretti, A., F. Rossi and R.V. Lanzone, Regio Museo di Torino: Antichità Egizie, I (Catalogo generale dei musei di antichità e degli oggetti d'arte raccolti nelle gallerie e biblioteche del regno, 1. Piemonte), Torino 1882.

Goyon, J.-Cl., "La fête de Sokaris à Edfou à la lumière d'un texte liturgique remontant au Nouvel Empire", BIFAO 78 (1978), pp. 415-38.

Graindorge, C., “Les oignons de Sokar”, RdÉ 43 (1992), pp. 87-105.

Graindorge, C., “L’oignon, la magie et les dieux”, in: S. Aufrère, (ed.), Encyclopédie religieuse de l'Univers végétal: croyances phytoreligieuses de l'Égypte ancienne, I (Orientalia Monspeliensia 11), Montpellier 1999, pp. 317-33.

Guidotti, M.C., "Il corredo funerario", in: F. Tiradritti, (ed.), Il Cammino di Harwa. L'uomo di fronte al mistero: l'Egitto, Milano 1999, pp. 106-119.

Habachi, H., "Amenwahsu Attached to the Cult of Anubis, Lord of the Dawning Land", MDAIK 14 (1956), pp. 52-62.

Habachi, L., "Nia, the Wab Priest and Doorkeeper of Amun-of-the-Hearing-Ear”, BIFAO 71 (1972), pp. 67-85.

Habachi, L., Tavole d'offerta, are e bacili da libagione, n. 22001-22067 (Catalogo del Museo Egizio di Torino, 2), Torino 1977.

Hayes, W.C., "Recent Additions to the Egyptian collection”, MMAB 7(1948-1949), 4, pp. 60-63.

Hayes, W.C. The Scepter of Egypt: A Background for the Study of the Egyptian Antiquities in The Metropolitan Museum of Art, II, The Hyksos Period and the New Kingdom (1675-1080 B.C.), New York 1959.

Helck, W., Zur Verwaltung des Mittleren und Neuen Reichs, Leiden 1958.

Humbert, J.-M., “La Description de l'Égypte, une source nouvelle pour l'égyptomanie”, in L'Égypte, une description: exposition du 2 avril au 31 août 1998 Musée Fesch Ajaccio, Ajaccio 1998.

Kees, H., "Kulttopographische und mythologische Beiträge”, ZÄS 71 (1935), pp. 107-12.

Koefoed-Petersen, O., Ny-Carlsberg Glyptotek: Catalogue des statues et statuettes égyptiennes, Copenhagen 1950.

$L G G$ = Leitz, C., Lexikon der ägyptischen Götter und Götterbezeichnungen, I-VII (OLA 110-116), Leuven 2002.

Lucas A. and J.R. Harris Ancient Egyptian Materials and Industries, Oxford 1962.

Manniche, L., The Tombs of the Nobles at Luxor, Cairo 1987.

Manniche, L., Lost Tombs: A Study of Certain Eighteenth Dynasty Monuments in the Theban Necropolis, London - New York 1988.

Manniche, L., Lost Ramessid and Post-Ramessid Private Tombs in the Theban Necropolis, Copenhagen 2011.

Marini, P., "I contenitori di ushabti nei musei italiani", EVO 35 (2012), pp. 83-124.

Marini, P., "I contenitori di ushabti: funzioni e concezioni" (PhD Thesis, University of Pisa), Pisa 2016.

Marini, P., "The Shabti-Boxes and Their Representation 
in Wall Paintings in Tombs at Deir el-Medina", in:

A. Dorn and S. Polis (eds.), Outside the Box: Selected Papers from the Conference "Deir el-Medina and the Theban Necropolis in Contact", Liège, 27-29 October 2014 (AegLeod 11), Liège (forthcoming).

Maspero, G., "Rapport sur une mission en Italie”, RT IV (1882), pp. 103-30.

Mekhitarian A., Egyptian Painting, Geneva 1978.

Moiso, B., La storia del Museo Egizio, Modena 2016.

Orcurti, P.C., Catalogo illustrato dei Monumenti Egizi del R. Museo di Torino compilato dal professore Pier Camillo Orcurti, Torino 1855.

PM I.1 = Porter, B. and R.L.B. Moss, Topographical Bibliography of Ancient Egyptian Hieroglyphic Texts, Relief and Paintings. I. The Theban Necropolis. Part 1: Private Tombs, Oxford 1994.

Posener-Kriéger, P., Les archives du temple funéraire de Néferirkarê-Kakaï (Les papyrus d'Abousir), Le Caire 1976.

Roccati, A., Itinerari dei Musei e Gallerie e Monumenti d'Italia, VII, Il Museo Egizio di Torino, Roma 1941.

Roccati, A., "Testi religiosi e funerari del secondo millennio a.C.”, in: A.M. Donadoni Roveri, Civiltà degli Egizi: le credenze religiose, Milano 1988, pp. 128-45.

Roccati, A., “La riscoperta continua dell'Egitto: preistoria delle collezioni torinesi”, in: C. Morigi Govi, S. Curto, and S. Pernigotti (eds.), L'Egitto fuori dell'Egitto: dalla riscoperta all'Egittologia, Bologna 1991, pp. 357-66.

Roehrig, C.H., R. Dreyfus and C.A. Keller (eds.), Hatshepsut: From Queen to Pharaoh, New Haven 2005. Seipel, W., Ägypten: Götter, Gräber und die Kunst. 4000 Jahre Jenseitsglaube, Linz 1989.

Trapani, M., "Imitation et interprétation dans l'art égyptien: le cas de quelques fragments de peintures murales de Deir el-Médineh", in: P. Collombert, D. Lefèvre, S. Polis and J. Winand, (eds.), Aere perennius. Mélanges égyptologiques en l'honneur de Pascal Vernus (OLA 242), Leuven - Paris - Bristol, CT 2016, pp. 81-124.

Urk. IV = Helck, W., Urkunden der 18. Dynastie. Biographische Inschriften von Zeitgenossen Thutmosis' III. und Amenophis' II., IV, Berlin 1956.

[Vidua, Carlo], “Collezione Drovetti, a. 1822. Catalogue de la collect. d'antiq. de mons. le chev. Drovetti”, in: Documenti inediti per servire alla storia dei musei d'Italia, III, Firenze - Roma 1880, pp. 206-292.

$W b=$ Erman, A. and H. Grapow, Wörterbuch der ägyptischen Sprache im Auftrage der Deutschen Akademien, I-VII, Leipzig - Berlin 1926-1963. 